\title{
PENGARUH KUALITAS PELAYANAN TERHADAP KEPUASAN SISWA LEMBAGA BIMBINGAN BELAJAR "POTENSI" PANYABUNGAN
}

\author{
Muhammad Isa ${ }^{1}$ \\ 1Institut Agama Islam Negeri Padangsidimpuan \\ ${ }^{1}$ Jl. H.T. Rizal Nurdin Km. 4,5 Sihitang, Padangsidimpuan, Sumatera Utara \\ 1 misatmm@gmail.com
}

\begin{abstract}
Good quality service will produce consumers who are always satisfied, and satisfied consumers usually become loyal consumers who are not tempted by promotions from other companies. The purpose of this research was to determine whether service quality give effect to student's satisfaction study at LEMBAGA BIMBINGAN BELAJAR "POTENSI". This research was quantitative research with 48 persons as samples. Then, the data collected by using questionnaires. The data analyzed by using simple regression and correlation through SPSS 17.o. The result of this research showed that service quality had a significant effect to student's satisfaction study at LEMBAGA BIMBINGAN BELAJAR "POTENSI". Service quality give effect or contribution to student's satisfaction study at LEMBAGA BIMBINGAN BELAJAR "POTENSI" about 66,3\% and about 33,7\% was effected by another variables.
\end{abstract}

Keywords : service quality, satisfaction, students

\begin{abstract}
Abstrak
Kualitas pelayanan yang baik akan menghasilkan konsumen yang selalu merasa puas, dan konsumen yang puas biasanya menjadi konsumen yang loyal yang tidak tergiur dengan promosi-promosi dari perusahaan lain. Tujuan penelitian ini adalah untuk mengetahui pengaruh kualitas pelayanan terhadap kepuasan siswa belajar di LEMBAGA BIMBINGAN BELAJAR "POTENSI". Penelitian ini adalah penelitian kuantitatif dengan ukuran sampel sebanyak 48 orang. Instrumen pengumpulan data menggunakan kuesioner. Kemudian data yang telah terkumpul dianalisis dengan teknik korelasi dan regresi sederhana dengan bantuan software SPSS 17.0. Hasil penelitian ini menunjukkan bahwa kualitas pelayanan memiliki pengaruh yang signifikan terhadap kepuasan siswa belajar di LEMBAGA BIMBINGAN BELAJAR "POTENSI". Kualitas pelayanan memberikan kontribusi terhadap kepuasan siswa belajar di LEMBAGA BIMBINGAN BELAJAR "POTENSI" sebesar 66,3\% dan sisanya 33, 7\% dipengaruhi oleh faktor lainnya.
\end{abstract}

Kata Kunci: kualitas pelayanan, kepuasan, siswa 


\section{PENDAHULUAN}

Setiap organisasi, baik yang bersifat nirlaba maupun profit oriented, tentunya berusaha untuk maju dan berkembang. Berkembang dan majunya suatu organisasi sangat dipengaruhi oleh sumber daya yang dimilikinya (internal) dan kondisi lingkungan eksternalnya. Situasi lingkungan eksternal organisasi, terutama lembaga yang profit oriented, akan menawarkan berbagai macam peluang bisnis yang "POTENSI"al untuk digarap sekaligus memberikan berbagai macam tantangan dan hambatan yang perlu dimanajemeni dengan baik agar tujuan organisasi dapat tercapai.

Salah satu tantangan yang dihadapi oleh berbagai macam organisasi perusahaan saat ini adalah ketatnya persaingan bisnis antar perusahaan serta selera konsumen yang mudah berubah dan makin sulit dipuaskan. Akibatnya hanya perusahaan yang benar-benar mengerti selera dan bisa memuaskan konsumen saja yang akan tetap diminati oleh pasar. Hal ini perlu menjadi perhatian setiap organisasi perusahaan mengingat keberadaan konsumen yang sangat penting bagi perusahaan. Tanpa adanya konsumen maka mustahil sebuah perusahaan dengan sumber daya unggul akan dapat maju dan berkembang. Oleh karena itu merupakan kewajiban manajemen perusahaan untuk memikirkan dan berupaya meningkatkan jumlah konsumen atau pelanggannya. Di sisi lain manajemen perusahaan harus menjaga loyalitas konsumen yang dimilikinya sekarang agar tidak berpaling ke perusahaan pesaing. Hal ini dapat dicapai dengan menjaga dan meningkatkan kepuasan konsumen secara berkesinambungan. Konsumen yang puas biasanya akan menjadi loyal atau setia menjadi pelanggan perusahaan. Konsumen yang loyal tidak akan mudah terpengaruh oleh promosi yang dilakukan oleh perusahaan pesaing. Konsumen yang loyal juga akan menjadi iklan gratis bagi perusahaan karena ia akan menceritakan pengalaman baiknya kepada orang lain dan sekaligus mengajak mereka untuk menjadi konsumen baru perusahaan. Hal itu semua dilakukannya tanpa meminta bayaran kepada pihak perusahaan. Konsumen yang loyal akan menjadi aset perusahaan yang berharga.

LEMBAGA BIMBINGAN BELAJAR "POTENSI", yang selanjutnya dalam tulisan ini sering ditulis dengan BIMBEL "POTENSI", merupakan suatu lembaga pendidikan swasta yang bergerak dalam kegiatan jasa pendidikan yaitu bimbingan belajar di luar sekolah yang diperuntukkan bagi siswa-siswi setingkat SMP dan SMA. Lembaga ini berada di Kota Panyabungan, Kabupaten Mandailing Natal, Sumatera Utara. Lembaga ini berusaha mempersiapkan siswa-siswi binaannya untuk lulus Ujian Nasional (UN) dan masuk ke SMA unggulan atau Perguruan Tinggi Negeri.

BIMBEL "POTENSI" merupakan lembaga pendidikan swasta. Sebagai lembaga pendidikan swasta harus diakui bahwa di samping tujuan formalnya sebagai lembaga pendidikan, lembaga ini juga bersifat mencari laba (profit oriented). Sumber pendapatan 
utama lembaga ini adalah sumbangan biaya pendidikan (tuition) yang dipungut dari setiap siswanya. Tentunya semakin banyak siswa yang dikelolanya akan semakin banyak pula pendapatan yang diterima lembaga ini. Hal ini akan berimbas kepada kesejahteraan staf pengajarnya dan kelengkapan sarana yang dimilikinya.

Lembaga pendidikan seperti ini bukanlah lembaga satu-satunya di Kabupaten Mandailing Natal. Di wilayah Kota Panyabungan ada beberapa lembaga sejenis antara lain Ganesha Operation, Pelita Bangsa, Juanda Course, dan English Junction. Setiap lembaga ini bersaing untuk menarik minat siswa-siswi SMP dan SMA yang ada di Kabupaten Mandailing Natal untuk menjadi siswa binaannya. Terkait dengan ketatnya persaingan ini maka sudah sewajarnya tiap lembaga tersebut berusaha untuk lebih meningkatkan kualitas pelayanannya dengan harapan siswanya tetap loyal dan jumlahnya makin banyak.

BIMBEL "POTENSI" harus selalu berusaha memberikan pelayanan yang berkualitas kepada siswa binaannya sehingga para siswa tersebut merasa puas. Dengan pelayanan yang memuaskan maka diharapkan tujuan BIMBEL "POTENSI" sebagai lembaga pendidikan sekaligus lembaga yang profit oriented akan tercapai. BIMBEL "POTENSI" perlu mengetahui sejauh mana kualitas pelayanan yang diberikannya berpengaruh terhadap kepuasan siswanya.

\section{TINJAUAN TEORITIK}

\subsection{Kualitas Pelayanan}

Menurut Kamus Besar Bahasa Indonesia kualitas adalah tingkat baik buruknya sesuatu. Menurut Adi Satrio kualitas merupakan baik buruknya suatu barang ataupun jasa (Adi Satrio, 2005). Menurut Wyckof dalam buku M. Nur Nasution kualitas adalah tingkat keunggulan yang diharapkan dan pengendalian atas tingkat keunggulan tersebut untuk memenuhi keinginan konsumen (Nasution, 2004). Menurut Geotsh dan Davis dalam buku Fandy Tjiptono dan G. Chandra kualitas adalah kondisi dinamis yang berhubungan dengan produk, jasa, sumber daya manusia, proses, dan lingkungan yang memenuhi atau melebihi harapan (Tjiptono dan Chandra, 2007). Kualitas apabila dikelola dengan tepat, berkontribusi terhadap terwujudnya kepuasan dan loyalitas konsumen. Kualitas memberikan nilai plus berupa motivasi khusus bagi konsumen untuk menjalin ikatan relasi saling menguntungkan dalam jangka panjang dengan perusahaan. Jadi kualitas adalah berpusat pada adanya upaya pemenuhan kebutuhan dan keinginan konsumen serta ketepatan penyampaiannya untuk mengimbangi harapan konsumen.

\subsection{Dimensi Kualitas Jasa}

Ada lima kriteria pokok kualitas pelayanan yang dikenal dengan dimensi kualitas pelayanan (Al-Arif, 2012), yaitu: bentuk fisik (Tangible), kehandalan (Realibility), ketanggapan (Responsiveness), jaminan (Assurance), dan empati (Empathy). 
Penjelasan kelima dimensi di atas adalah sebagai berikut (Ratnasari dan Aksa, 2011) Pertama, Tangible: adalah kemampuan perusahaan/lembaga dalam menunjukkan eksistensinya kepada pihak eksternal. Penampilan dan kemampuan sarana dan prasarana perusahaan/lembaga serta keadaan lingkungan sekitarnya merupakan bukti nyata dari pelayanan yang diberikan pemberi jasa, ini meliputi fasilitas fisik (gedung, gudang, fasilitas fisik, dan lainnya), teknologi (peralatan dan perlengkapan yang digunakan), serta penampilan pegawainya. Kedua, Reliability: yaitu kemampuan perusahaan/lembaga untuk memberikan pelayanan sesuai dengan yang dijanjikan secara akurat dan terpercaya. Harus sesuai dengan harapan konsumen, berarti kinerja yang tepat waktu, pelayanan tanpa kesalahan, sikap simpatik, dan dengan akurasi tinggi. Ketiga, Responsiveness: yaitu suatu kemauan untuk membantu dan memberikan pelayanan yang cepat (responsive) dan tepat kepada konsumen, dengan penyampaian informasi yang jelas. Membiarkan konsumen untuk menunggu terlalu lama untuk dilayani tanpa alasan yang jelas, menyebabkan persepsi yang negatif dalam kualitas jasa. Keempat, Assurance: yaitu pengetahuan, kesopan-santunan, dan kemampuan para pegawai perusahaan untuk menumbuhkan rasa percaya konsumen kepada perusahaan. Terdiri atas komponen: komunikasi, kredibilitas, keamanan, kompetensi, dan sopan santun. Kelima, Empathy: yaitu memberikan perhatian, tulus, dan bersifat individual atau pribadi kepada konsumen dengan berupaya memahami keinginannya, dimana suatu perusahaan/lembaga diharapkan memiliki suatu pengertian dan pengetahuan tentang konsumen, memahami kebutuhan konsumen secara spesifik, serta menjaga kenyamanan konsumen.

\subsection{Prinsip Kualitas dan Manajemen Jasa}

Ada enam pokok prinsip dalam kualitas jasa ( Wolkins dalam Nasution, 2004). Pertama: Kepemimpinan, yaitu strategi kualitas perusahaan harus merupakan inisiatif dan komitmen dari manajemen puncak. Manajemen puncak harus memimpin perusahaan untuk meningkatkan kinerja kualitasnya. Tanpa adanya kepemimpinan manajemen puncak, maka usaha untuk meningkatkan kualitas hanya berdampak kecil terhadap perusahaan. Kedua: Pendidikan, yaitu seluruh personil mulai dari manajer puncak sampai karyawan operasional harus memperoleh pendidikan mengenai kualitas. Aspek-aspek yang perlu mendapatkan penekanan dalam pendidikan meliputi konsep kualitas sebagai strategi bisnis, alat dan teknik implementasi strategi kualitas, dan peranan eksekutif dalam implementasi strategi kualitas. Ketiga, Perencanaan: yaitu proses perencanaan strategi harus mencakup pengukuran dan tujuan kualitas yang dipergunakan dalam mengarahkaan perusahaan dalam mencapai visinya. Keempat, Review: proses ini merupakan satu-satunya alat yang penting dan paling efektif bagi manajemen untuk mengubah perilaku organisasi. Proses ini merupakan suatu mekanisme yang menjamin adanya perhatian yang konstan dan kontinu untuk mencapai 
tujuan mutu. Kelima, Komunikasi: dalam hal ini komunikasi harus dilakukan dengan karyawan, konsumen dan stakeholder perusahaan lainnya mengenai implementasi strategi dan perbaikan kualitas jasa. Keenam, Penghargaan dan pengakuan: yaitu setiap karyawan yang berprestasi baik perlu diberikan penghargaan. Sehingga dapat meningkatkan motivasi, moral kerja, rasa bangga dan rasa memiliki dalam organisasi, yang akhirnya dapat memberikan kontribusi besar bagi perusahaan dan bagi konsumen yang dilayani.

\subsection{Kualitas Pelayanan Menurut Perspektif Islam}

Islam sangat mendorong umatnya untuk melakukan pekerjaan yang berkualitas, seperti dijelaskan dalam Al-Qur'an surah Al-Baqarah ayat 267:

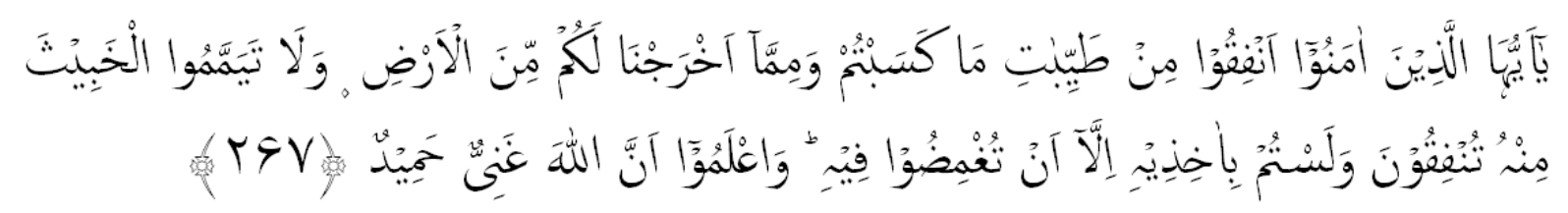

Artinya: Hai orang-orang yang beriman, nafkahkanlah (di jalan Allah) sebagian dari hasil usahamu yang baik-baik dan sebagian dari apa yang kami keluarkan dari bumi untuk kamu dan janganlah kamu memilih yang buruk-buruk lalu kamu menafkahkan daripadanya. Padahal kamu sendiri tidak mau mengambilnya melainkan dengan memicingkan mata terhadapnya, dan ketahuilah bahwa Allah Maha Kaya lagi Maha Terpuji.

Dalam ayat di atas secara tersirat mengajak manusia untuk berkarya dengan karya terbaik. Pada lembaga yang bergerak dalam bidang jasa, termasuk lembaga pendidikan, harus mengoptimalkan penggunaan segala sumber daya yang dimilikinya untuk memberikan pelayanan yang terbaik.

\subsection{Kepuasan Konsumen}

Menurut Kamus Besar Bahasa Indonesia kepuasan merupakan perihal (yang bersifat) puas, kesenangan, kelegaan.

Kepuasan konsumen juga didefenisikan sebagai evaluasi si pembeli, dimana alternatif yang dipilih sekurang-kurangnya memberikan hasil (outcome) sama atau melampaui harapan konsumen (Engel, et.al dalam Nasution, 2004). Oleh karena itu dapat dikatakan bahwa kepuasan konsumen dapat tercapai jika konsumen merasakan keinginan , kebutuhan dan harapan dalam proses mendapatkan, mengkonsumsi hingga menghabiskan produk/jasa merasa terpenuhi.

Suatu hal yang perlu diperhatikan di sini adalah strategi kepuasan konsumen. Strategi kepuasan konsumen adalah strategi yang dapat dipadukan untuk meraih dan meningkatkan kepuasan konsumen, diantaranya sebagai berikut: 1) mengidentifikasi siapa konsumen sebenarnya, 2) memahami tingkat harapan konsumen, 3) memahami strategi kualitas pelayanan konsumen. 4) memahami siklus pengukuran dan umpan balik dari konsumen. 


\subsection{Sifat-Sifat Konsumen}

Untuk dapat memuaskan konsumen maka organisasi harus memahami sifat-sifat konsumen. Setiap konsumen tentu memiliki karakteristik yang berbeda antara satu dengan lainnya. Pertama, konsumen mau dianggap sebagai raja: artinya perusahaan harus menganggap konsumen sebagai raja yang harus dipenuhi semua keinginan dan kebutuhannya. Pelayanan yang diberikan haruslah seperti melayani dan menuruti kemauan seorang raja. Kedua, mau dipenuhi keinginan dan kebutuhannya: artinya konsumen menginginkan agar kebutuhannya dapat terpenuhi mulai dari hal yang paling sederhana sampai yang kompleks. Ketiga, tidak mau didebat dan tidak mau disinggung: artinya konsumen tidak suka didebat, oleh karena itu perusahaan perlu menyikapi komentar konsumen secara hati-hati agar mereka merasa tidak dibantah atau didebat. Keempat, konsumen mau diperhatikan: artinya perhatian yang diberikan kepada konsumen adalah mulai dari konsumen datang sampai dengan berakhirnya pelayanan yang diberikan. Perhatian yang diberikan mulai dari sikap, cara berbicara dan lainnya. Kelima, konsumen ingin selalu dipuji: artinya ujian atau sanjungan yang diberikan kepada konsumen akan sangat bermanfaat. Misalnya konsumen merasa senang berhubungan dengan perusahaan kita dan ingin selalu mengulang transaksinya. Ada semacam kebanggaan bagi konsumen karena merasa memperoleh perhatian dari perusahaan. Keenam, konsumen merupakan sumber pendapatan perusahaan: atinya perusahaan selalu menganggap bahwa setiap konsumen yang datang merupakan sumber pendapatan perusahaan. Dengan demikian, hendaknya setiap personil perusahaan termotivasi untuk melayani konsumen dengan sebaikbaiknya (Kasmir, 2008).

\section{METODE PENELITIAN}

Penelitian ini dilaksanakan di BIMBEL "POTENSI" yang beralamat di Jl. Kol. H.M. Nurdin Nasution Desa Panyabungan Julu, Kecamatan Panyabungan, Kabupaten Mandailing Natal, Sumatera Utara. Berdasarkan metodenya penelitian ini dilakukan dengan metode kuantitatif. Sumber data dalam penelitian ini diperoleh dari sumber primer dan skunder. Data primer diperoleh dengan cara penyebaran kuesioner langsung kepada para siswa BIMBEL "POTENSI". Data sekunder dalam penelitian ini diperoleh dari pihak pengelola BIMBEL "POTENSI" maupun pihak lain yang relevan, yang menjadi populasi dalam penelitian ini adalah keseluruhan siswa BIMBEL "POTENSI" yang berjumlah 48 orang yaitu sebanyak 18 orang siswa setingkat SMP dan 30 orang dalam penelitian ini adalah seluruh siswa BIMBEL "siswa setingkat SMA. 


\section{Pengaruh Kualitas Pelayanan Terhadap Kepuasan siswa Lembaga Bimbingan Belajar "Potensi" Panyabungan}

Dalam aturan penentuan jumlah sampel apabila subyeknya kurang dari 100, lebih baik diambil semua sehingga penelitiannya merupakan penelitian populasi (Arikunto, 2006). Oleh karena itu seluruh populasi sebanyak 48 orang dalam penelitian ini otomatis diteliti karena jumlah populasinya kurang dari 100 unit. Sehingga penelitian ini merupakan penelitian populasi.

Instrumen penelitian ini adalah dengan menggunakan kuesioner. Butir kuesioner yang digunakan sebanyak 20 butir yang diturunkan dari indikator masing-masing variabel sebagai berikut:

Tabel 1. Indikator-indikator variabel.

\begin{tabular}{|c|c|}
\hline Variabel & Dimensi \\
\hline Kualitas Pelayanan (X) & $\begin{array}{l}\text { 1) Kenyamanan lokasi } \\
\text { 2) Penampilan staf/pegawai } \\
\text { 3) Fasilitas memadai } \\
\text { 4) Menghargai dan mengerti keluhan } \\
\text { konsumen } \\
\text { 5) Meyakinkan dan menanamkan rasa percaya } \\
\text { 6) Pelayanan yang sopan dan ramah } \\
\text { 7) Memberikan informasi lengkap } \\
\text { 8) Menyelesaikan keluhan dengan cepat } \\
\text { 9) Waktu pelayanan sesuai dengan janji } \\
\text { 10) Memberikan garansi pekerjaan }\end{array}$ \\
\hline Kepuasan Konsumen (Y) & $\begin{array}{l}\text { 1) Produk yang diterima sesuai dengan janji } \\
\text { 2) Dapat memenuhi kebutuhan yang diinginkan } \\
\text { 3) Produk yang ditawarkan memuaskan } \\
\text { 4) Merasa bangga menjadi konsumen } \\
\text { 5) Sesuai dengan harga/biaya } \\
\text { 6) Konsumen merekomendasikan lembaga } \\
\text { kepada orang lain } \\
\text { 7) Tidak terpengaruh dengan promosi lembaga } \\
\text { 8) Tidain ragu dengan kualitas produk yang } \\
\text { diterima } \\
\text { 9) Menceritakan pengalaman baik kepada } \\
\text { orang lain } \\
\text { 10) Setia dengan produk lembaga. }\end{array}$ \\
\hline
\end{tabular}

Sumber: data diolah

Responden akan mengisi kuesioner tersebut dan selanjutnya peneliti akan mengkuantifikasinya sebelum diolah dengan software SPSS versi 17.0 menurut penilaian 
berikut: a) Jawaban sangat setuju sekali diberi bobot 5 , b) Jawaban sangat setuju diberi bobot 4, c) Jawaban setuju diberi bobot 3, d) Jawaban kurang setuju diberi bobot 2, e) Jawaban tidak setuju diberi bobot 1.

Sebelum disebarkan kepada responden, maka butir-butir kuesioner tersebut diuji validitas dan realibilitas terlebih dahulu. Hanya butir-butir kuesioner yang valid dan reliabel yang digunakan dalam tahapan penelitian selanjutnya. Uji validitas bertujuan untuk memastikan instrumen yang digunakan benar-benar dapat mengukur apa yang hendak diukur sedangkan uji reliabilitas bertujuan untuk mengukur kekonsistenan instrumen yang digunakan. Untuk uji validitas dan reliabilitas pengujiannya dilakukan dengan uji dua sisi menggunakan taraf signifikansi 0,05.

Selanjutnya dilakukan uji normalitas dan uji linearitas. Kedua uji ini merupakan syarat untuk dapat dilakukannya analisis regresi sederhana. Data yang diperoleh dari kuesioner selanjutnya dianalisis dengan analisis korelasi sederhana. Analisis ini digunakan untuk mengetahui keeratan hubungan antara dua variabel dan untuk mengetahui arah hubungan yang terjadi. Koefisien korelasi sederhana menunjukkan seberapa besar hubungan yang terjadi antara dua variabel. Dalam penelitian ini akan digunakan metode Product Moment Pearson. Nilai koefisien korelasi ( $\mathrm{r}$ ) berkisar antara 1 sampai -1. Apabila nilai $\mathrm{r}$ semakin mendekati 1 atau -1 berarti hubungan antara dua variabel makin kuat, sebaliknya nilai mendekati o berarti hubungan antara dua variabel makin lemah. Nilai positif $(+)$ menunjukkan hubungan searah dan sebaliknya negatif (-) menunjukkan hubungan terbalik.

Menurut Sugiyono pedoman untuk memberikan interpretasi koefisien korelasi sebagai berikut (Dwi Priyatno, 2008):

$$
\begin{array}{ll}
\text { 0,00 }-0,1999 & =\text { sangat rendah } \\
0,20-0,399 & =\text { rendah } \\
0,40-0,599 & =\text { sedang } \\
0,60-0,799 & =\text { kuat } \\
0,80-1,000 & =\text { sangat kuat }
\end{array}
$$

Selanjutnya dihitung nilai koefisien determinasi $\left(\mathrm{r}^{2}\right)$ yang digunakan untuk mengetahui persentase sumbangan pengaruh variabel independen $(\mathrm{X})$ terhadap variabel dependen (Y).

Langkah berikutnya adalah melakukan analisis regresi linear sederhana untuk mengetahui arah hubungan antara variabel independen dengan variabel dependen apakah positif atau negatif dan untuk memprediksi nilai variabel dependen apabila nilai variabel independen mengalami kenaikan atau penurunan. Rumus regresi linear sederhana adalah sebagai berikut (Dwi Priyatno, 2008):

$$
\mathrm{Y}^{`}=\mathrm{a}+\mathrm{bX}
$$

Keterangan: $\quad Y^{`}=$ variabel dependen (nilai yang diprediksikan)

$$
\mathrm{X}=\text { variabel independen }
$$


162 Pengaruh Kualitas Pelayanan Terhadap Kepuasan siswa Lembaga Bimbingan Belajar "Potensi" Panyabungan

$\mathrm{a}=$ konstanta (nilai $\mathrm{Y}^{`}$ apabila $\mathrm{X}=\mathrm{O}$ )

$\mathrm{b}=$ koefisien regresi (nilai peningkatan atau penurunan)

Selanjutnya dilanjutkan perhitungan uji t. Uji ini digunakan untuk mengetahui apakah variabel bebas $(\mathrm{X})$ berpengaruh secara signifikan terhadap variabel terikat $(\mathrm{Y})$.

Kriteria pengujiannya adalah:

$P$ value $>0,05$ artinya tidak ada pengaruh yang signifikan variabel bebas terhadap variabel terikat.

Pvalue $<0,05$ artinya ada pengaruh yang signifikan variabel bebas terhadap variabel terikat.

\section{HASIL DAN PEMBAHASAN}

\subsection{Gambaran Umum dan Sejarah Singkat BIMBEL "POTENSI"}

BIMBEL "POTENSI" merupakan lembaga pendidikan swasta. Lembaga ini bergerak dalam usaha bimbingan belajar untuk siswa setingkat SMP dan SMA. Lembaga ini bertujuan untuk memberikan pendidikan di luar sekolah agar siswa binaannya lulus menempuh Ujian Nasional (UN), lulus ke SMA favorit atau Perguruan Tinggi Negeri (PTN).

BIMBEL "POTENSI" berlokasi di Jalan Kol. H.M. Nurdin Nasution Desa Panyabungan Julu, Kecamatan Panyabungan, Kabupaten Mandailing Natal, Sumatera Utara. Lembaga ini memiliki gedung permanen milik sendiri dan berada lebih kurang $2 \mathrm{~km}$ dari pusat kota Panyabungan. Lokasi BIMBEL "POTENSI" mudah dijangkau dengan kenderaan umum dari berbagai penjuru kota Panyabungan.

Lembaga ini berdiri pada tahun 2007. Lembaga ini didirikan oleh Bapak Muhammad Syukri, S.Si., S.Pd. dan keluarga. Lembaga ini membagi siswanya dalam 2 kelompok yaitu kelompok belajar setingkat SMP dan setingkat SMA. Kegiatan belajar dilakukan mulai jam 15.15 WIB sampai 17.0o WIB. Kegiatan belajar diasuh oleh 4 orang tenaga pendidik.

\subsection{Hasil Uji Validitas dan Reliabilitas}

Uji validitas dan reliabilitas dilakukan untuk menguji kesahihah dan ketepatan instrumen penelitian. Instrumen yang digunakan dalam penelitian ini adalah kuesioner yang disebarkan kepada seluruh siswa BIMBEL "POTENSI" sebanyak 48 orang.

Dari pengolahan data yang telah dilakukan dengan software SPSS versi 17.0 diperoleh hasil untuk variabel kualitas pelayanan sebagai berikut: 
Tabel 2. Hasil Uji validitas variabel kualitas pelayanan

\begin{tabular}{|c|c|c|c|c|}
\hline & $\begin{array}{c}\text { Scale } \\
\text { Mean if } \\
\text { Item } \\
\text { Deleted }\end{array}$ & $\begin{array}{c}\text { Scale } \\
\text { Variance if } \\
\text { Item Deleted }\end{array}$ & $\begin{array}{c}\text { Corrected } \\
\text { Item-Total } \\
\text { Correlation } \\
\end{array}$ & $\begin{array}{c}\text { Cronbach's Alpha if } \\
\text { Item Deleted }\end{array}$ \\
\hline VARoooo1 & 26.50 & 11.277 & .507 & .821 \\
\hline VARoooo2 & 26.15 & 11.574 & .586 & .815 \\
\hline VARoooo3 & 26.06 & 10.443 & .689 & .801 \\
\hline VARoooo4 & 25.81 & 10.964 & .592 & .812 \\
\hline VARoooo5 & 26.13 & 11.686 & .393 & .833 \\
\hline VARoooo6 & 26.13 & 11.303 & .491 & .823 \\
\hline VARoooo7 & 26.08 & 12.121 & .424 & .828 \\
\hline VARoooo8 & 26.13 & 11.218 & .554 & .816 \\
\hline VARoooo9 & 26.42 & 11.270 & .519 & .820 \\
\hline VARooo10 & 25.79 & 11.700 & .511 & .821 \\
\hline
\end{tabular}

Dari tabel $r$ pada signifikansi o,o5 dengan uji 2 sisi dan jumlah data $(n)=48$ diperoleh $\mathrm{r}$ tabel sebesar 0,285.

Dari hasil analisis dapat dilihat bahwa untuk semua item nilainya lebih besar dari 0,285 sehingga dapat disimpulkan semua butir kuesioner untuk variabel kualitas pelayanan (X) adalah valid. Selanjutnya untuk variabel kepuasan siswa diperoleh tabel berikut:

Tabel 3. Hasil Uji validitas variabel kepuasan siswa

\begin{tabular}{lcccc}
\hline & $\begin{array}{c}\text { Scale Mean } \\
\text { if Item } \\
\text { Deleted }\end{array}$ & $\begin{array}{c}\text { Scale } \\
\text { Variance if } \\
\text { Item Deleted }\end{array}$ & $\begin{array}{c}\text { Corrected } \\
\text { Item-Total } \\
\text { Correlation }\end{array}$ & $\begin{array}{c}\text { Cronbach's Alpha } \\
\text { if Item Deleted }\end{array}$ \\
\hline VARoo001 & 27.52 & 13.361 & $\mathbf{7 7 9}$ & .844 \\
VARoo002 & 27.56 & 14.847 & $\mathbf{. 5 1 8}$ & .866 \\
VARoo003 & 27.65 & 14.148 & $\mathbf{. 6 3 7}$ & .857 \\
VARoo004 & 27.40 & 13.648 & $\mathbf{. 8 0 3}$ & .844 \\
VARoo005 & 27.67 & 15.418 & $\mathbf{. 4 4 4}$ & .871 \\
VARoo006 & 27.58 & 15.567 & $\mathbf{. 3 4 3}$ & .880 \\
VARo0007 & 27.44 & 13.783 & $\mathbf{. 7 5 0}$ & .848 \\
VARo0008 & 27.71 & 15.190 & $\mathbf{. 4 6 6}$ & .870 \\
VARo0009 & 27.48 & 14.510 & $\mathbf{. 6 5 8}$ & .856 \\
VARo0010 & 27.44 & 14.847 & $\mathbf{. 5 4 2}$ & .864 \\
\hline
\end{tabular}

Dari tabel $r$ pada signifikansi o,o5 dengan uji 2 sisi dan jumlah data $(n)=48$ diperoleh $\mathrm{r}$ tabel sebesar 0,285.

Dari hasil analisis dapat dilihat bahwa untuk semua item nilainya lebih besar dari o,285 sehingga dapat disimpulkan semua butir kuesioner untuk variabel kepuasan siswa (Y) adalah valid. 


\section{Pengaruh Kualitas Pelayanan Terhadap Kepuasan siswa Lembaga Bimbingan Belajar "Potensi" Panyabungan}

Selanjutnya dilakukan uji reliabilitas instrumen. Dari pengolahan data yang telah dilakukan dengan software SPSS versi 17.0 diperoleh hasil untuk variabel kualitas pelayanan sebagai berikut:

\section{Tabel 4. Hasil Uji reliabilitas variabel kualitas pelayanan}

\begin{tabular}{cc}
\hline Cronbach's Alpha & N of Items \\
\hline .834 & 10
\end{tabular}

Dari tabel di atas diperoleh nilai Alpha sebesar 0,834. Karena nilai alpha > 0,6 atau o,834> o,6 maka dapat disimpulkan bahwa semua butir-butir instrumen untuk variabel kualitas pelayanan adalah reliabel. Selanjutnya untuk variabel kepuasan siswa diperoleh tabel berikut:

Tabel 5. Hasil Uji reliabilitas variabel kepuasan siswa

\begin{tabular}{cc}
\hline Cronbach's Alpha & N of Items \\
\hline .873 & 10 \\
\hline
\end{tabular}

Dari tabel di atas diperoleh nilai Alpha sebesar 0,873. Karena nilai alpha $>0,6$ atau o,873>0,6 maka dapat disimpulkan bahwa semua butir-butir instrumen untuk variabel kepuasan siswa adalah reliabel.

\subsection{Uji Normalitas}

Dari pengolahan data yang telah dilakukan dengan software SPSS versi 17.0 ternyata komputer mengeluarkan grafik seperti berikut:

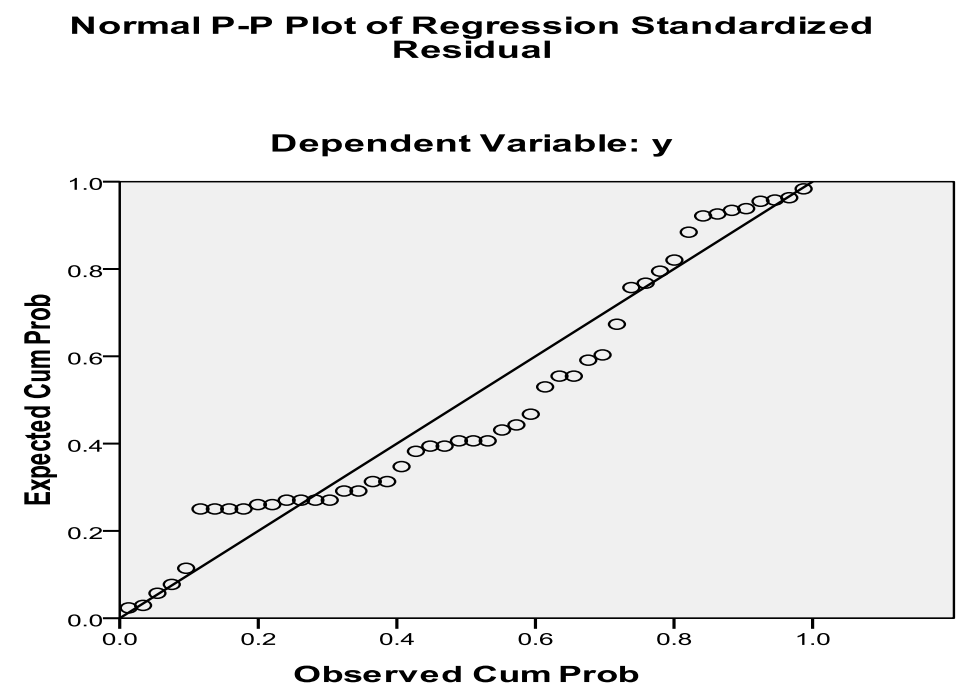

Gambar 1. Hasil Uji normalitas 
Dari gambar di atas tampak bahwa data menyebar di sekitar garis diagonal dan mengikuti arah garis diagonal tersebut, maka dapat disimpulkan bahwa model regresi memenuhi asumsi normalitas.

\subsection{Uji Linieritas}

Uji ini bertujuan untuk mengetahui apakah dua variabel mempunyai hubungan yang linear atau tidak secara signifikan. Hal ini menjadi prasyarat untuk dilakukannya analisis korelasi atau regresi linear.

Hasil pengolahan data dengan software SPSS versi 17.0 memunculkan tabel berikut:

Tabel 6. Hasil Uji linearitas

\begin{tabular}{lccc}
\hline & $\begin{array}{c}\text { Sig. } \\
\text { Linearity }\end{array}$ & Sig. & Keterangan \\
\hline Kualitas Pelayanan Terhadap Kepuasan siswa & 0,000 & 0,05 & $\begin{array}{c}\text { Terdapat } \\
\text { hubungan } \\
\text { linear }\end{array}$ \\
\hline
\end{tabular}

Dari tabel di atas dapat diketahui bahwa signifikansi pada Linearity adalah sebesar o,ooo. Karena signifikansi kurang dari 0,05 maka dapat disimpulkan bahwa antara variabel kualitas pelayanan dan kepuasan siswa terdapat hubungan yang linear.

\subsection{Perhitungan Koefisien Korelasi}

Dari pengolahan data yang telah dilakukan dengan software SPSS versi 17.0 diperoleh tabel seperti berikut:

Tabel 7. Koefisien korelasi

\begin{tabular}{c|ccc}
\hline \multicolumn{2}{c}{ Variabel } & Pearson Correlation & Keterangan \\
\hline Kualitas Pelayanan & Kepuasan Siswa & 0,815 & Hubungannya kuat \\
\hline
\end{tabular}

Dari hasil analisis korelasi (r) diperoleh korelasi antara kualitas pelayanan (X) dengan kepuasan siswa (Y) sebesar o,815. Oleh karena itu dapat disimpulkan bahwa antara kualitas pelayanan (X) dengan kepuasan siswa $(\mathrm{Y})$ terdapat hubungan yang sangat kuat.

\subsection{Analisis Regresi Linier Sederhana}

Dari pengolahan data yang telah dilakukan dengan software SPSS versi 17.0 diperoleh tabel seperti berikut:

Tabel 8. Regresi linear sederhana

\begin{tabular}{cc}
\hline Variabel & Unstandardized Coefficients \\
\hline (Constant) & 3,807 \\
Kualitas Pelayanan & 0,923 \\
\hline
\end{tabular}


166 Pengaruh Kualitas Pelayanan Terhadap Kepuasan siswa Lembaga Bimbingan Belajar "Potensi" Panyabungan

Dari tabel tersebut dapat dibentuk persamaan regresi linear untuk kedua variabel (kualitas pelayanan dan kepuasan siswa) seperti berikut ini:

$$
\mathbf{Y}^{`}=\mathbf{3}, \mathbf{8 0 7}+\mathbf{0 , 9 2 3} \mathrm{X}
$$

Dari persamaan tersebut dapat dijelaskan bahwa antara variabel kualitas pelayanan (X) dan variabel kepuasan siswa (Y) memiliki hubungan yang searah (+). Artinya jika kualitas pelayanan (X) makin meningkat maka akan mengakibatkan meningkatnya pula kepuasan siswa (Y).

Kemudian setiap peningkatan variabel kualitas pelayanan (X) sebesar 1 persen akan berakibat meningkatnya nilai variabel kepuasan siswa (Y) sebesar 0,923 persen. Sebaliknya setiap pengurangan variabel kualitas pelayanan (X) sebesar 1 persen akan berakibat berkurangnya nilai variabel kepuasan siswa (Y) sebesar 0,923 persen.

\subsection{Uji t}

Uji t digunakan untuk mengetahui ada atau tidaknya pengaruh variabel independen terhadap variabel dependen secara parsial, dapat dilihat pada tabel berikut.

Tabel 9 Hasil Uji t

\begin{tabular}{cccl}
\hline & $\begin{array}{c}\text { Sig. } \\
\text { Variabel }\end{array}$ & Sig. & Keterangan \\
\hline Kualitas Pelayanan & 0,000 & 0,05 & Terdapat Pengaruh \\
\hline
\end{tabular}

Dari Tabel 7 diperoleh $P$ value $=0,000$. Karena $P$ value $<0,05$ atau 0,000 $<0,05$ maka dapat disimpulkan bahwa ada pengaruh yang signifikan variabel kualitas pelayanan terhadap variabel kepuasan siswa.

\subsection{Koefisien Determinasi}

Hasil pengolahan data dengan software SPSS versi 17.0 memperlihatkan tabel berikut:

Tabel 1o. Koefisien Determinasi

\begin{tabular}{|l|c|c|c|}
\hline \multicolumn{1}{|c|}{ Model } & R & R Square & $\begin{array}{c}\text { Adjusted R } \\
\text { Square }\end{array}$ \\
\hline 1 & 0,815 & 0,663 & 0,656 \\
\hline
\end{tabular}

Dari tabel di atas terlihat bahwa $\mathrm{r}$ square $\left(\mathrm{r}^{2}\right)$ atau yang sering disebut koefisien determinasi sebesar o,663 atau 66,3 persen. Hal ini menjelaskan bahwa variabel kualitas pelayanan (X) memberikan pengaruh sebesar 66,3 persen terhadap variabel kepuasan siswa (Y) sedangkan sisanya 33,7 persen dipengaruhi oleh variabel lain yang tidak diteliti dalam penelitian ini.

\subsection{Pembahasan Hasil Penelitian}

At-Tijaroh : Jurnal Ilmu Manajemen dan Bisnis Islam, Volume 5, Nomor 1 Tahun 2019 http://jurnal.iain-padangsidimpuan.ac.id/index.php/attijaroh 
Dari hasil pengolahan data yang dilakukan menunjukkan adanya keterkaitan yang sangat kuat antara kualitas pelayanan (X) dengan kepuasan siswa (Y). Hal ini terbukti dari nilai $\mathrm{r}$ sebesar 0,815 . Oleh karena itu dalam rangka meningkatkan kepuasan siswa dalam belajar maka pihak manajemen BIMBEL "POTENSI" harus memperhatikan aspek kualitas pelayanan. Kemudian dari persamaan regresi yang diperoleh: $\mathrm{Y}^{`}=3,807+0,923 \mathrm{X}$ menunjukkan adanya hubungan yang positif atau searah. Hal ini mengisyaratkan bahwa setiap usaha meningkatkan kualitas pelayanan akan meningkatkan secara signifikan kepuasan siswa dalam belajar. Faktor kualitas ini sangat penting untuk dikelola dengan baik apabila pihak manajemen BIMBEL "POTENSI" ingin memuaskan siswanya dalam mengikuti kegiatan belajar mengingat besarnya kontribusi pengaruh kualitas pelayanan terhadap kepuasan siswa yaitu sebesar 66,3 persen, tentunya tanpa melupakan aspek-aspek lainnya di luar kualitas pelayanan, misalnya promosi, biaya, materi pembelajaran, dan garansi.

Hasil penelitian ini sejalan dengan teori dalam ilmu manajemen antara lain menurut Garvin dalam buku Jamal Ma'mur Asmani yang menyatakan bahwa kepuasan pelanggan salah satunya dipengaruhi oleh kualitas produk/pelayanan yang dipersepsikan oleh pelanggan (Asmani, 2015).

Oleh karena itu salah satu strategi dalam rangka menghadapi dan memenangkan persaingan untuk merebut simpati calon siswa adalah dengan memberikan kepuasan kepada siswa dalam belajar di LEMBAGA BIMBINGAN BELAJAR "POTENSI". Para siswa yang puas diharapkan akan loyal kepada BIMBEL "POTENSI” dan akan mengajak rekan-rekan mereka untuk menjadi siswa BIMBEL "POTENSI". Mereka juga diharapkan akan memberitahukan pengalaman baiknya kepada orang lain sekaligus mempromosikan BIMBEL "POTENSI". Dalam rangka meningkatkan kepuasan siswa dalam belajar maka pihak manajemen BIMBEL "POTENSI" berkewajiban untuk selalu menjaga dan meningkatkan kualitas pelayanannya.

\section{KESIMPULAN}

Dari paparan di atas, dapat disimpulkan ada pengaruh yang signifikan variabel kualitas pelayanan terhadap kepuasan siswa BIMBEL "POTENSI". Hubungan yang terjadi adalah hubungan yang sangat kuat dan searah (+). Artinya jika kualitas pelayanan (X) makin meningkat maka akan mengakibatkan meningkatnya pula kepuasan siswa (Y).

Dari perhitungan koefisien determinasi diketahui bahwa variabel kualitas pelayanan (X) memberikan pengaruh sebesar 66,3 \% terhadap variabel kepuasan siswa (Y) sedangkan sisanya 33,7 \% dipengaruhi oleh variabel lain yang tidak diteliti dalam penelitian ini. 
168 Pengaruh Kualitas Pelayanan Terhadap Kepuasan siswa Lembaga Bimbingan Belajar "Potensi" Panyabungan

\section{DAFTAR PUSTAKA :}

Adi Satrio, Kamus Ilmiah Populer, Jakarta: Visi 7, 2005.

Departemen Agama, Al-Qur'an dan terjemahannya, Bandung: Diponegoro,1991.

Dwi Priyatno, Mandiri Belajar SPSS, Yogyakarta: MediaKom, 2008.

Fandy Tjiptono dan G. Chandra, Service Quality Satisfaction ,Yogyakarta: Andi, 2007.

Jamal Ma'mur Asmani, Manajemen Efektif Marketing Sekolah ,Yogyakarta:DIVA Press, 2015 .

Kasmir, Etika Costumer Service , Jakarta: Raja Grafindo Persada, 2008.

M. Nur Nasution, Manajemen Jasa Terpadu, Jakarta: Ghalia, 2004.

M. Nur Rianto Al Arif, Dasar-dasar Pemasaran Bank Syariah, Bandung:Alfabeta, 2012.

Muhammad Teguh, Metode Penelitian Ekonomi Teori dan Aplikasi, Jakarta: PT.Raja Grafindo Persada, 2005.

Ririn Tri Ratnasari dan Mastuti H. Aksa, Manajemen Pemasaran Jasa , Bogor: Ghalia Indonesia, 2011.

Sugiyono, Metode Penelitian Bisnis, Bandung : Alfabeta, 2001.

Suharsimi Arikunto, Prosedur Penelitian Suatu Pendekatan Praktek, Jakarta : Rineka Cipta, 2006.

Tim Penyusun Kamus Pusat Bahasa, Kamus Besar Bahasa Indonesia, Jakarta: Balai Pustaka, 2001. 